\title{
Identification of Teasterone and Phytosterols in the Lipid Fraction from Seeds of Cannabis sativa L.
}

\author{
Suguru TAKAtsuto*1, Takahiro KAWASHimA*1, Takahiro NoGUChi*2, \\ Shozo FUJIOKA*3, and Akira SAKURAI*3 \\ *1 Department of Chemistry, Joetsu University of Education \\ (Joetsu-shi, Niigata-ken, $\mathbf{T}^{943)}$ \\ *2 Tama Biochemical Co. Ltd. \\ (Shinjuku-ku, Tokyo, ₹163) \\ *3 The Institute of Physical and Chemical Research (RIKEN) \\ (Wako-shi, Saitama-ken, $\bar{\top} 351-01$ )
}

\begin{abstract}
Study was made of brassinosteroids and phytosterols in unsaponifiable lipid obtained from the seeds of Cannabis sativa L. Bioactive substances in a rice-lamina inclination test were highly purified, derivatized and analyzed by GC-MS. The brassinosteroid, teasterone, was identified, suggesting for the first time its possible presence as a fatty acid ester in dicot plants. Phytosterols in the seeds were found to contain six phytosterols, cholesterol, campesterol, campestanol, stigmasterol, sitosterol and sitostanol, with sitosterol and campesterol present in the largest amounts. Campestanol and sitostanol were identified in the seeds for the first time. The structural relationship between brassinosteroids and phytosterols in the seeds is discussed from a biosynthetic point of view.
\end{abstract}

Key words : Cannabis sativa L., brassinosteroid, teasterone, campestanol, sitostanol

\section{Introduction}

Research on distribution of brassinosteroids (BRs), steroidal plant growth regulators, in plants has clarified that BRs occur in many higher plants and also in some lower plants and that up to date more than 40 natural BRs have been chemically characterized ${ }^{1), 2)}$. Screening investigation has been focused on free form of BRs, because of their high biological activity. Recently, the natural occurrence of BR fatty acid esters, teasterone 3-myristate and its 3laurate, has been reported in the hexane-soluble fraction obtained from the lily anthers by Abe and co-workers $^{3), 4)}$. We have also reported the possible presence of the fatty acid esters of teasterone and its 3-epimer, typhasterol, in the hexane-soluble fraction obtained from the anthers of Erythronium japonicum Decne ${ }^{5)}$. Very recently, Abe and co-workers have also reported the possible presence of the fatty acid esters of teasterone, typhasterol, and some BRs with lower polarity in the hexane-soluble fraction obtained from the pollen of Typha latifolia $\mathrm{L}^{6}$. The above-reported three plants are monocot plants. However, with respect to the dicot plants, there is no information of the occurrence of BR esters. In our previous paper, we have reported the identification of teasterone and castasterone (Fig. 1) as a free form in a chloroform-soluble fraction obtained from the methanol extract of the seeds of Cannabis sativa $\mathrm{L}^{7)}$. Although the hexane-soluble fraction obtained from the methanol extract of the seeds was found to be inactive in the rice-lamina inclination test, which is known to be highly specific to $\mathrm{BRs}^{8}{ }^{8}$, the above-described recent reports on BR esters have prompted us to re-investigate the hexane fraction. Interestingly, it has been now found that an unsaponifiable lipid obtained from the hexane fraction was found to be active in the bioassay.

Corresponding author : Suguru TAKATSUTO 

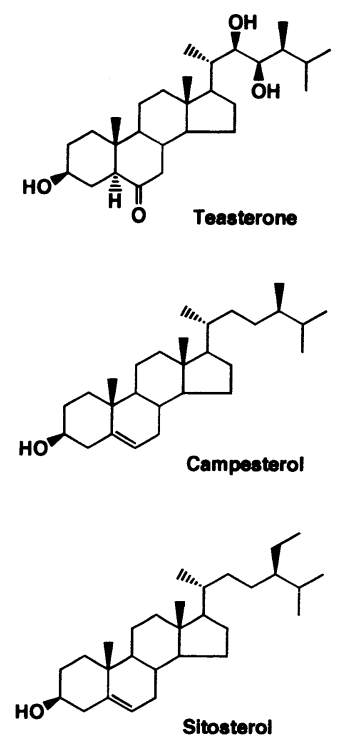
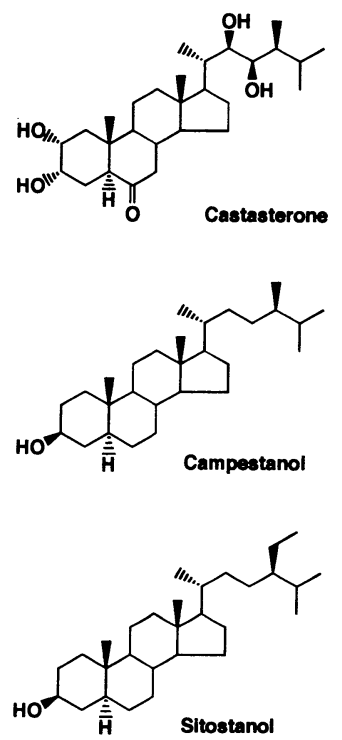
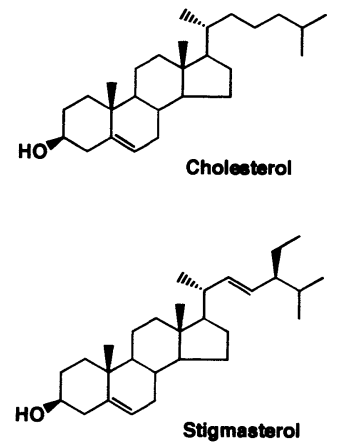

Fig. 1 Structures of Brassinosteroids and Phytosterols Identified in the Seeds of Cannabis sativa L.

Therefore, it is suggested that BRs esters should be present and that the biological activity elicited by BR esters is nullified by unknown compounds, because it has been demonstrated that teasterone fatty acid esters showed high biological activity ${ }^{9}$. In order to have a more hint for the occurrence of BR fatty acid esters in the plant kingdom and also to get an information on what kinds of BRs are present as esters in the seeds of $C$. sativa, we have re-examined BRs contained in the hexane fraction obtained from the seeds. In this paper, we report the identification of BRs in the unsaponifiable lipid and also the composition of phytosterols in the seeds, because the $\mathrm{C}_{28}$ sterols are assumed to be the biosynthetic precursors of the $\mathrm{C}_{28} \mathrm{BRs}$.

\section{Experimental}

\subsection{Authentic steroids}

Cholesterol was purchased from Wako Pure Chemical Industries Co. Ltd., Osaka, Japan, and campesterol, stigmasterol, sitosterol, campestanol, and sitostanol were kindly supplied by Tama Biochemical Co. Ltd., Tokyo, Japan. Castasterone and teasterone were synthesized as described in our previous paper $\left.{ }^{10)}, 11\right)$.

\subsection{Bioassay}

Purification of a BR fraction was monitored by a rice-lamina inclination test, which was carried out using etiolated seedings of rice (Oryza sativa L. cv. Nipponbare), according to the reported method ${ }^{8)}$.

\subsection{Hexane fraction from the seeds}

As described in our previous paper ${ }^{7}$, the hexane-soluble fraction $(41.2 \mathrm{~g})$ was obtained by solvent partitioning of the methanol $(\mathrm{MeOH})$ extract of the seeds $(2.1 \mathrm{~kg})$ of $C$. sativa.

\subsection{Saponification of the hexane fraction}

The hexane fraction ( $41.2 \mathrm{~g}$ ) was treated with $10 \% \mathrm{NaOH}$ in $80 \%$ aqueous $\mathrm{MeOH}(300 \mathrm{~mL})$ at $100^{\circ} \mathrm{C}$ for $2 \mathrm{~h}$. Work-up (diethyl ether-toluene, $1: 1$, vol/vol) gave an unsaponifiable lipid $(9.37 \mathrm{~g})$.

\subsection{Column chromatography of the unsaponifiable fraction}

The lipid $(9.37 \mathrm{~g})$ was charged onto a column of silica gel $(3.5 \mathrm{~cm}$ i.d. $\times 20.0 \mathrm{~cm}$, Kieselgel 
60, 70 230 mesh, Merck). Elution was carried out stepwise with increasing concentration of ethyl acetate (EtOAc) in toluene and, after elution with sterol fractions, then with $20 \%$ $\mathrm{MeOH}$ in EtOAc. Eluates with 2 and $4 \%$ EtOAc in toluene were combined to give a sterol fraction $(4.34 \mathrm{~g})$. An eluate with $20 \% \mathrm{MeOH}$ in EtOAc was concentrated to give a BR fraction $(1.91 \mathrm{~g})$.

\subsection{Purification of a BR fraction}

The BR fraction $(1.91 \mathrm{~g})$ was chromatographed on silica gel $(2.5 \mathrm{~cm}$ i.d. $\times 21.5 \mathrm{~cm})$ eluting stepwise with $0,0,2,2,4,6,8,10,12,15,20,30$, and $100 \% \mathrm{MeOH}$ in chloroform $\left(\mathrm{CHCl}_{3}\right)$ (each fraction $100 \mathrm{~mL}$ ). Eluates with $4 \sim 15 \% \mathrm{MeOH}$ in $\mathrm{CHCl}_{3}$ were combined $(0.29 \mathrm{~g}$ ) and then applied to a column of reversed-phase silica gel $(2.0 \mathrm{~cm}$ i.d. $\times 20 \mathrm{~cm}$, Kieselgel 60 silanisiert, 70 230 mesh, Merck). Elution was done stepwise with 50, 50, 50, 67, 75, 80, 83, 83, 100 , and $100 \% \mathrm{MeOH}$ in $\mathrm{H}_{2} \mathrm{O}$ (each fraction $50 \mathrm{~mL}$ ). A strongly active eluate with $75 \% \mathrm{MeOH}$ in $\mathrm{H}_{2} \mathrm{O}$ was concentrated to give a fraction $\mathrm{A}-\mathrm{a}(25 \mathrm{mg})$. Weakly active eluates with 80 and 83 (first fraction) $\% \mathrm{MeOH}$ in $\mathrm{H}_{2} \mathrm{O}$ were combined into a fraction $\mathrm{A}-\mathrm{b}(113 \mathrm{mg})$.

The fraction A-a $\left(25 \mathrm{mg}\right.$ ) was purified by preparative TLC (Kieselgel $60 \mathrm{~F}_{254}, 20 \mathrm{~cm} \times 20$ $\mathrm{cm}, 0.25 \mathrm{~mm}$ thickness, Merck) with EtOAc-ethanol $(22: 3$, vol/vol). Active fractions with $R_{F} 0.48 \sim 0.73$ were concentrated to give a fraction $B-1(2.2 \mathrm{mg})$. In the same manner, the fraction $\mathrm{A}-\mathrm{b}(113 \mathrm{mg})$ were purified by preparative TLC to give an active fraction $\mathrm{B}-2$ (12.8 $\mathrm{mg})$ with $\mathrm{R}_{\mathrm{F}} 0.44 \sim 0.80$.

The fractions B-1 and B-2 were combined $(15 \mathrm{mg})$ and purified by preparative TLC (Kieselgel 60 silanisiert, $20 \mathrm{~cm} \times 20 \mathrm{~cm}, 0.25 \mathrm{~mm}$ thickness, Merck) with $\mathrm{MeOH}-\mathrm{H}_{2} \mathrm{O}(3: 1$, $\mathrm{vol} / \mathrm{vol}$ ). Active fractions with $\mathrm{R}_{\mathrm{F}} 0.38 \sim 0.53$ were combined to give a $\mathrm{BR}$ fraction $\mathrm{C}$ (5.2 $\mathrm{mg})$.

\subsection{GC-MS analysis of BRs}

One-third of the fraction $\mathrm{C}$ was methaneboronated and then trimethylsilylated, as described in a previous paper ${ }^{12)}$. GC-MS was carried out as previously described ${ }^{12)}$.

\subsection{Purification of a fraction of phytosterols}

The crude sterol fraction $(4.34 \mathrm{~g})$ was charged onto a column of silica gel $(3.0 \mathrm{~cm}$ i.d. $\times 20$ $\mathrm{cm}$ ) and eluted with toluene-EtOAc (50:1 to $25: 1$, vol/vol). Eluates with toluene-EtOAc (25 $: 1, \mathrm{vol} / \mathrm{vol})$ containing sterols were combined and concentrated to give a sterol fraction (1.25 $\mathrm{g})$. This fraction was further chromatographed on silica gel $(3.0 \mathrm{~cm}$ i.d. $\times 25 \mathrm{~cm})$ eluting with hexane-EtOAc $(20: 1$ to $3: 1$, vol/vol $)$. Eluates with hexane-EtOAc $(3: 1, \mathrm{vol} / \mathrm{vol}) \mathrm{con}$ taining 4-desmethylsterols were combined to provide a fraction of phytosterols $(0.67 \mathrm{~g})$.

\subsection{Isolation of a saturated phytosterol fraction}

The phytosterol fraction $(100 \mathrm{mg})$ was acetylated with acetic anhydride $(1 \mathrm{~mL})$ and pyridine $(2 \mathrm{~mL})$ at room temperature overnight. Work-up (EtOAc) gave a crude sterol acetate, which in $\mathrm{CHCl}_{3}(5 \mathrm{~mL})$ was then treated with $\mathrm{m}$-chloroperbenzoic acid $(80 \mathrm{mg})$ at room temperature overnight. Work-up (EtOAc) gave a crude product, which was chromatographed on silica gel $(2.0 \mathrm{~cm}$ i.d. $\times 20 \mathrm{~cm})$ with hexane-toluene $(1: 1$ to $0: 1, \mathrm{vol} / \mathrm{vol})$ to give the fractions of stanol acetate. These combined fractions in tetrahydrofuran $(4 \mathrm{~mL})$ was treated with $5 \% \mathrm{KOH}$ in $\mathrm{MeOH}(2 \mathrm{~mL})$ at room temperature overnight. Work-up (diethyl ether) followed by purification by preparative TLC $(20 \mathrm{~cm} \times 20 \mathrm{~cm}, 0.5 \mathrm{~mm}$ thickness $)$ with toluene-EtOAc (10:1, vol/vol) provided a saturated phytosterol fraction $(2.4 \mathrm{mg})$.

2.10 GC-MS analysis of phytosterols

A Shimadzu GC-MS QP-5000 equipped with a fused silica ULBON HR-1 capillary column ( $50 \mathrm{~m} \times 0.25 \mathrm{~mm}$ i.d., $0.25 \mu \mathrm{m}$ film thickness, Shimadzu) was used under the following conditions : ionization, electron impact mode $(70 \mathrm{eV})$; mass range, 100 550 ; scan interval, $0.5 \mathrm{~s}$. ; injection temp., $300^{\circ} \mathrm{C}$; interface temp., $250^{\circ} \mathrm{C}$; carrier gas, helium ; carrier gas pressure, $170 \mathrm{kPa}$; total flow rate, $50 \mathrm{~mL} / \mathrm{min}$, split ratio $61: 1$, flow rate, $0.7 \mathrm{~mL} / \mathrm{min}$; column temp., $300^{\circ} \mathrm{C}$. 
A small portion $(0.5 \mathrm{mg})$ of each sterol fraction was derivatized as a trimethylsilyl (TMS) ether by treatment with $N$-trimethylsilylimidazole $(100 \mu \mathrm{L})$ and pyridine $(50 \mu \mathrm{L})$ at $60^{\circ} \mathrm{C}$ for $30 \mathrm{~min}$.

Relative retention times $\left(R t_{R}\right)$ to cholesterol TMS ether $(13.741 \mathrm{~min}$ ) and mass spectral data (characteristic fragment ions) of the identified phytosterols as TMS ethers were as follows. Cholesterol TMS ether, $R t_{R}, 1.000, \mathrm{MS} \mathrm{m} / z$ (rel. int.) : $458\left(\mathrm{M}^{+}, 19\right), 443$ (17), $368(20)$, 353 (22), 329 (23), 247 (15), 129 (100). Campesterol TMS ether, $R t_{R}, 1.179, \mathrm{MS} \mathrm{m} / z: 472\left(\mathrm{M}^{+}\right.$, 13), 457 (4), 382 (29), 367 (12), 343 (30), 255 (10), 129 (100). Campestanol TMS ether, Rt $t_{R}$, 1.202, MS m/z: $474\left(\mathrm{M}^{+}, 34\right), 459$ (42), 417 (12), 384 (33), 369 (23), 306 (35), 230 (19), 215 (100), 201 (16), 147 (57), 121 (29), 107 (75). Stigmasterol TMS ether, Rt $\mathrm{R}_{\mathrm{R}}, 1.231, \mathrm{MS} \mathrm{m} / z$ : $484\left(\mathrm{M}^{+}, 16\right), 394$ (19), 379 (8), 355 (25), 351 (7), 342 (8), 282 (9), 255 (36), 129 (64). Sitosterol TMS ether, $R \mathrm{t}_{\mathrm{R}}, 1.360, \mathrm{MS} m / z: 486\left(\mathrm{M}^{+}, 10\right), 471$ (3), 396 (23), 381 (10), 357 (23), 329 (2), 275 (5), 255 (8), 129 (100). Sitostanol TMS ether, $\mathrm{Rt}_{\mathrm{R}}, 1.379, \mathrm{MS} m / z: 488\left(\mathrm{M}^{+}, 31\right), 473(42)$, 431 (13), 398 (20), 383 (30), 359 (5), 306 (33), 290 (9), 257 (12), 230 (23), 215 (100), 201 (20), 147 (36), 121 (47), 107 (95).

\section{Results and Discussion}

The hexane-soluble fraction, obtained from the $\mathrm{MeOH}$ extract of the seeds of $C$. sativa ${ }^{7}$, was saponified and the unsaponifiable lipid was chromatographed on silica gel to give a sterol fraction and a BR fraction. At first, the BR fraction was further purified, as described in Experimental, to give an active fraction $C$ with $R_{F} 0.38 \sim 0.53$. The $R_{F}$ value of the fraction corresponds to those of authentic teasterone and castasterone, suggesting the occurrence of these BRs.

The active fraction $\mathrm{C}$ was methaneboronated and analyzed by GC-MS. However, castasterone could not be detected. Thus, the derivatized fraction $\mathrm{C}$ was further trimethylsilylated and analyzed by GC-MS, affording an incomplete mass spectrum of a teasterone methaneboronate-TMS derivative, because of the abundant intensity of background ions and also its inadequate purity. In the GC-selected ion monitoring (SIM) anaylsis (Fig. 2), however, characteristic fragment ions at $m / z 544\left(\mathrm{M}^{+}\right), 529\left(\mathrm{M}^{+}-15\right)$, and $515\left(\mathrm{M}^{+}-29\right)$ of the teasterone

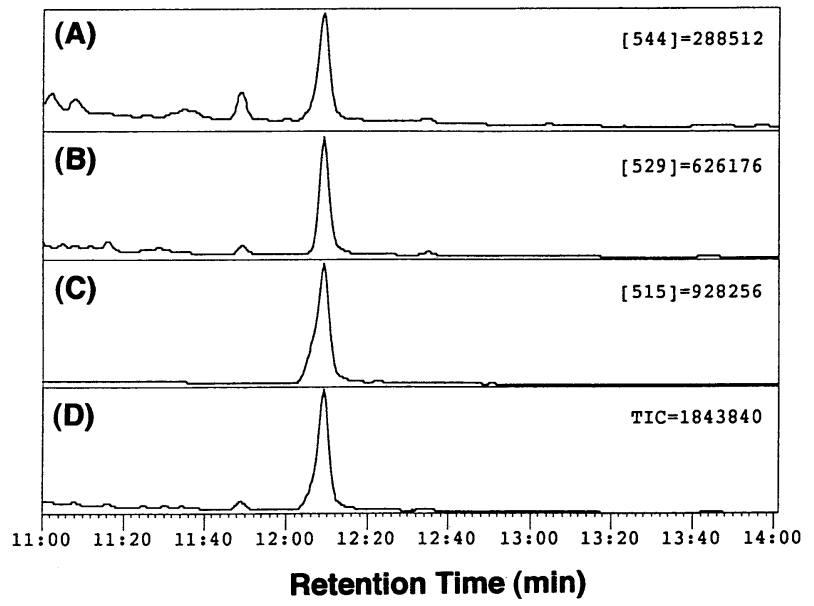

Fig. 2 GC-SIM of Characteristic Ions at $m / z 544\left[\mathrm{M}^{+},(\mathrm{A})\right]$, $529\left[\mathrm{M}^{+}-15,(\mathrm{~B})\right]$, and $515\left[\mathrm{M}^{+}-29,(\mathrm{C})\right]$ of a Teasterone Methaneboronate-TMS Derivative and Total Ion Chromatogram (D), Obtained from the Bioactive Fraction C.

These characteristic ions were observed at $12.15 \mathrm{~min}$. 
derivative were observed, and their relative intensity and retention time $(12.15 \mathrm{~min})$ were identical with those of the authentic sample. The amount of teasterone in the bioactive fraction $\mathrm{C}$ was roughly estimated by GC-SIM to be $c a .2 .3 \mu \mathrm{g} / \mathrm{kg}$ fresh weight of the seeds.

Therefore, BR contained in the unsaponifiable lipid of the hexane-soluble fraction obtained from the mature seeds of $C$. sativa was rigorously identified to be teasterone. It is suggested that teasterone is originally present as an ester form. Thus, the present result coupled with our previous data ${ }^{7)}$ strongly suggests that in the seeds of $C$. sativa, teasterone occurs as both free and ester forms and castasterone occurs as a free from. Although what kind of fatty acids are esterified with teasterone remains for further investigation, the present data suggests for the first time the possibility that BRs occur as an ester form not only in the monocot plants ${ }^{3) \sim 6)}$, but also in dicot plants.

Next, we investigated the composition of phytosterols in the seeds of $C$. sativa, because of their importance as biosynthetic precursors to BRs. The sterol fraction, obtained by silica gel column of the unsaponifiable lipid, was purified, as described in Experimental, to obtain a phytosterol fraction. This was analyzed by GC-MS after trimethylsilylation. The respective sterol TMS ether was identified by direct comparison with authentic samples. The phytosterols identified and the composition (indicated in parenthesis), which was obtained by total ion chromatogram, were as follows : cholesterol (0.53\%), campesterol (16.01), campestanol (0.45), stigmasterol (5.00), sitosterol (70.12), and sitostanol (6.82). Two unidentified sterols accounted for $1.06 \%$. Because of the difficulty of separation of stereoisomers at the C-24 position of the 24-alkylsterols under our analytical condition, it is unknown whether or not the 24-alkylsterols are mixed with each $\mathrm{C}-24$ stereoisomer. In this paper, we tentatively used the common names.

Since the mass spectrum of campestanol was incomplete and contaminated with unknown background ions, we have further investigated the very minor campestanol in the seeds. From the isolated phytosterol fraction, sterols with carbon-carbon double bond (s) were removed, as described in Experimental. The resulting saturated phytosterol fraction was analyzed by GC-MS after trimethylsilylation, affording clear sharp peaks of the TMS derivatives of campestanol and sitostanol. By direct comparison with authentic samples, campestanol and sitostanol were rigorously identified in the seeds of $C$. sativa by the full-scan mass spectral data.

The present identification is roughly consistent with the reported data of the seeds, in which campesterol, stigmasterol, and sitosterol were identified as major sterols ${ }^{13) \sim 17)}$. It was also reported that campesterol, stigmasterol, sitosterol, $5 \alpha$-ergostan-3-one, $5 \alpha$-stigmastan-3-one, 5 $\alpha$-stigmast-22-en-3-one, and 5,24(28)-unsaturated sterol were identified from the callus of $C$. sativa ${ }^{18)}$. However, to the best of our knowledge, the present study is the first report of the identification of campestanol and sitostanol in C. sativa.

With respect to the biosynthesis of BRs, among the phytosterols identified, campesterol and campestanol have the same carbon skeleton as those of teasterone and castasterone. Recently, Fujioka and co-workers have reported that in cultured cells of Catharanthus roseus, campesterol and campestanol are the most plausible biosynthetic precursors of the $\mathrm{C}_{28}$ $\mathrm{BRs}^{19), 20)}$. Futhermore, they have very recently demonstrated that the det 2 mutant of Arabidopsis thaliana is the BR-deficient mutant and the step of the conversion of campesterol into campestanol is blocked in the BR biosynthesis ${ }^{21), 22)}$. Coupled with these reported data and our previous identification of the $\mathrm{C}_{28} \mathrm{BRs}$ in the seeds of C. sativa ${ }^{7)}$, the present identification of campesterol and campestanol suggests that campesterol and campestanol are involved in the BR biosynthesis and these two sterols selectively serve as biosynthetic precursors to the $\mathrm{C}_{28} \mathrm{BRs}$. 


\section{Acknowledgement}

The authors thank Mr. Katsuya Shimada and Miss Kana Makiuchi of Joetsu University of Education for their technical assistance.

(Received Apr. 17, 1997 ; Accepted Sept. 26, 1997)

\section{References}

1) S. Fujioka, A. Sakurai, Nat. Prod. Rep., 14, 1. (1997).

2) S. Takatsuto, J. Chromatogr. A, 658, 3 (1994).

3) S. Asakawa, H. Abe, Y. Kyokawa, S. Nakamura, M. Natsume, Biosci. Biotech. Biochem., 58, 219 (1994).

4) S. Asakawa, H. Abe, N. Nishikawa, M. Natsume, M. Koshioka, Biosci. Biotech. Biochem., 60, 1416 (1996).

5) E. Yasuta, T. Terahata, M. Nakayama, H. Abe, S. Takatsuto, T. Yokota, Biosci. Biotech. Biochem., 59, 2156 (1995).

6) K. Mukai, H. Abe, M. Natsume, Abstract of the 31st Annual Meeting of the Japanese Society for Chemical Regulation of Plants (in Japanese), (Kyoto), p. 53 (1996).

7) S. Takatsuto, H. Abe, T. Yokota, K. Shimada, K. Gamoh, J. Jpn. Oil Chem. Soc., 45, 871 (1996).

8) M. Arima, T. Yokota, N. Takahashi, Phytochemistry, 23, 1587 (1984).

9) H. Abe, M. Aburatani, Jpn. Pat., 6-25281 (1994).

10) S. Takatsuto, J. Chem. Soc., Perkin Trans. I, 1986, 1833.

11) S. Takatsuto, N. Yazawa, M. Ishiguro, N. Morisaki, N. Ikekawa, J. Chem. Soc., Perkin Trans., I, 1984, 139.

12) H. Suzuki, S. Fujioka, S. Takatsuto, T. Yokota, N. Murofushi, A. Sakurai, J. Plant Growth Regul., 13, 21 (1994).

13) C. Fenselau, G. Hermann, J. Forensic Sci., 17, 309 (1972).

14) T. Itoh, T. Tamura, T. Matsumoto, J. Am. Oil Chem. Soc., 50, 122 (1973).

15) R. S. Foote, L. A. Jones, J. Agric. Food Chem., 22, 534 (1974).

16) M. L. Mole Jr., C. E. Turner, J. Pharm. Sci., 63, 154 (1974).

17) T. M. Jeong, T. Itoh, T. Tamura, T. Matsumoto, Lipids, 9, 921 (1974).

18) H. Itokawa, K. Takeya, M. Akasu, Shoyakugaku Zasshi, 29, 106 (1975).

19) S. Fujioka, A. Sakurai, Chem. Regul. Plants (Shokubutsu no Kagaku Chousetsu, review in Japanese), 30, 137 (1995).

20) H. Suzuki, T. Inoue, S. Fujioka, T. Saito, S. Takatsuto, T. Yokota, N. Murofushi, T. Yanagisawa, A. Sakurai, Phytochemistry, 40, 1391 (1995).

21) S. Fujioka, Y.-H. Choi, S. Takatsuto, T. Yokota, J. Li, J. Chory, A. Sakurai, Abstract of the 31st Annual Meeting of the Japanese Society for Chemical Regulation of Plants (in Japanese), (Kyoto), p. 41 (1996).

22) J. Li, P. Nagpal, V. Vitart, A. Chao, S. Fujioka, Y.-H. Choi, M. Guha-Biswas, T. C. McMorris, S. Takatsuto, T. Yokota, D. W. Russell, A. Sakurai, J. Chory, Proc. Plant Growth Regul. Soc. Am., 23, 11 (1996). 


\section{[ノート ］アササ種子中より得られた脂質中に含まれる ティーステロン及び植物ステロールの同定}

高津戸 秀 ${ }^{* 1} \cdot$ 川島 崇弘 ${ }^{* 1} \cdot$ 野口 貴弘 ${ }^{* 2}$ 藤岡 昭三*3 ・桜井 成 ${ }^{* 3}$

$* 1$ 上越教育大学自然系化学教室 ( $\overline{\mathbf{T}} 943$ 新潟県上越市山屋敷町 1 )

*2 夕マ生化学 (下163 東京都新宿区西新宿 2-7-1)

$* 3$ 理化学研究所植物生活環制御研究室 (下351-01 埼玉県和光市広沢 2-1)

アサ種子中から得られた不けん化脂質中に含まれるブラシノステロイドと植物ステロールについて調べた。イネ 葉身屈曲試験において活性な物質を精製し, 誘導体化後 GC-MS 分析を行った。ブラシノステロイドの一種であ るティーステロンを同定したことから，このものが双子葉植物中に脂肪酸エステルとして存在する可能性が初めて 示唆された。また，種子中に含まれる植物ステロールについて調べ，6種のステロール（コレステロール，カンペ ステロール，カンペスタノール，スティグマステロール，シトステロール及びシトスタノール）を同定したとこ ろ，カンペステロールとシトステロールが主成分であった。カンペスタノールとシトスタノールはアサ種子中から 初めて同定された。アサ種子中に含まれるブラシノステロイドと植物ステロールとの関係について, 生合成的観点 から論じた。 